\title{
Metaphorical-Enactive: Al-Ghazali's Education Media on Sufism Themes
}

\author{
Suwito $^{1}$, Muflihah ${ }^{2}$, Abdul Wachid BS ${ }^{3}$, Suparjo ${ }^{4}$, Ali Mas'ud ${ }^{5}$, Corry Aina Widaputri ${ }^{6}$ \\ \{suwitons@iainpurwokerto.ac.id ${ }^{1}$ \} \\ Institut Agama Islam Negeri (IAIN) Purwokerto, Indonesia 1,2,3,4 \\ Universitas Islam Negeri Sunan Ampel (UINSA) Surabaya, Indonesia ${ }^{5}$ \\ Universitas Islam Negeri (UIN) Sunan Gunung Djati, Bandung, Indonesia ${ }^{6}$
}

\begin{abstract}
This study aimed to explore and discuss the educational media used by AlGhazali relevant to essential concepts in Sufism. The role of the qalb in Sufism is very urgent in human life and for every Muslim. Because of this, Al-Ghazali has been very intense in describing this complex concept in the long discussion in his book. The explanation of qalb is fascinating and unique because al-Ghazali has managed to break down complex concepts into simple ones using the media he used. There are at least four media used to explain the miracle of the existence and the role of qalb in humans, namely 1) mirror, 2) kingdom, 3) fortresses, and 4) lakes. The data of this study were collected by a literature study, especially in the book Ihya 'Ulum al-Din Part III, and Bidayat alHidayah. The collected data were then read through Bruner's Learning Media Theory. The results of the research showed that al-Ghazali used the media to convey Sufism concepts, such as 1) media objects familiar to people living in the 12th century (such as mirrors, fortresses, and lakes), 2) environmental media such as the environment of the community and the role of the apparatus. The media used by al-Ghazali can stimulate a detailed mental image from the lowest to the highest levels of ability, namely imagination (al-quwwah alkhayaliyah), estimation (al-quwwah al-wahmiyah), and thinking (aqliyah), which in Bruner's term is called metaphorical-enactive.
\end{abstract}

Keywords: Sufism, education media, learning media, qalb

\section{Introduction}

Tasawuf (sufism), as a science, has many concepts and terms [1]-[4]. Its spiritual terms are often abstract and confusing, especially for beginners (mubtadi'in). The concepts of spirit, soul, nafs, their potentials as well as how they work are often considered difficult and complicated matters [4]-[6].

For a teacher, the success of explaining concepts that students can understand is very important. To achieve student understanding, learning media is needed in the teaching and learning process. Basically, learning media is an intermediate "channel" (in Islamic term is called wasilah) used in the learning process in order to facilitate learners to successfully understand the concept. This understanding will encourage them to experience the knowledge (idrak) [7]-[9] and learners will continuously apply and embed it in their lives, which finally becomes their habit [10], [11]. Al-Ghazali has a unique strategy and media to explain the concepts in Sufism studies. This article will explore the style of media used by al-Ghazali in 
relation to the delivery of Sufism concepts, which are very abstract, complex, and subtle, such as the concept of qalb (heart), its characteristics, and how it works.

\section{Method}

The data of this article were taken from al-Ghazali's work in Ihya 'Ulum al-Din, especially Book III. The collected data was sorted according to the relevance of data needs in this research. Furthermore, the data were analyzed using content analysis by Bruner's media theory and Ibn Sina's theory about learner modalities

\section{Results and Discussion}

\subsection{Metaphor-Enactive Theories in Learning Media and Sufism Context}

Among the learning objectives is maturity, which is marked by a change in attitude, which basically can occur because of a change in consciousness [12]. This statement is in line with the opinion of Ibn Sina (d.1032), who said that someone's actions are usually based on perception, knowledge, or understanding (idrak). Change in consciousness usually starts with knowledge or understanding. Lickona formulates the degree of understanding from the knowing level to the feeling level, and the feeling will be compelled to doing [13]-[15]. This ongoing practice was originally formatted through the educational process [16], and then spontaneously attached to oneself, which is usually called character or morals.

In the context of knowledge achievement, Bruner suggests that there are three levels of knowledge that a learner can achieve, which is parallel with the media used, namely enactive, iconic, and symbolic. Enactive level refers to direct learning process, in which learners directly involve in the learning process [17]-[19]. and they learn by doing either physically or spiritually/psychologically (in Islamic term it is called halli or hudhuri). Iconic level refers to one level below, i.e. learning by watching or seeing. In enactive level, all aspects of the learners are involved during the learning process, while in iconic level, the dominant aspect involved is the visual one. The next is the symbolic level, which, according to Bruner, is the lowest level of learning. In this level, a teacher uses verbal and literal symbols to deliver the materials [20][23].

In relation to enactive level, Gallager and Lindgren stated that enactive metaphors used in learning and the involvement of all parts of the body in the virtual environment and mixed reality can provide enhanced learning [24], [25]. In addition, Herik [26], [27] stated that learning will be more effective with an ecological-enactive approach, namely the delivery of concepts with words combined with attention action in the form of repetition of attitudes practiced by a person. Herik also wrote about enactive level in learning music [28]-[32]. Rojas explained that the use of enactive approaches for non-mathematical students is very good for describing a concept. [33], [34] in Jin research on Evolutionary Enactive Learning (EEL), it is indicated that EEL can be developed through ready machine-based learning techniques.

Sufism is the spiritual or esoteric aspect of Islam [35]-[39]. Sufism discusses the spiritual aspects of man and is connected with the Supreme Being, Allah, to obtain a noble character [40]-[45]. Important themes in the study and practice of Sufism include matters of self-struggle, heart management, and control of lust [46]-[50]. Therefore, the main theme of Sufism is 
emptying the heart from badness (takhalli), filling the goodness of the heart (tahalli), and implementing goodness in the reality of life (tajalli) [51]-[54].

There are some key concepts that students (prospective Sufi) must understand before practicing spiritual empowerment. Among these concepts is a comprehensive understanding of the spirit, heart (qalb) and lust (nafs) along with their characteristics, attributes, and categories. Understanding concrete concepts about the heart will lead students to be able to recognize their characteristics, uniqueness, and categories.

\subsection{Al-Ghazali's Profil dan His Work}

The full name of al-Ghazali is Muhammad bin Muhammad bin Muhammad bin Ahmad alThusi, who is known by the name laqab Abu Hamid. He was born in 450 Hijriyah / 1058 A.D in Thus, 15 miles north of Mashad, Iran [55], [56]. Nasab scholars argued about the origin of his name. The name al-Ghazali was partly based on his father's profession, al-Ghazzal, namely "the wool weaver" and partly attributed to his region, Ghazal [57].

Little Al-Ghazali learned from his father. He learned fiqh from his teacher, Shaykh Ahmad bin Muhammad al-Radzakani. Before passing away, his father entrusted him to a Sufi who was also a close friend of him. Al-Ghazali also learned from Imam Haramain in Nisabur until he mastered Syafi'i fiqh, manthiq, kalam, and philosophy. After his teacher died, al-Ghazali went to the camp of Wazir Nidzamul Mulk. There was a council of scholars. At that time, al-Ghazali challenged them to debate. By supplying the vastness of knowledge and mastering manthiq, alGhazali was able to defeat them. Finally, Nidzam al-Mulk appointed him as an instructor at its madrasah in Baghdad. In the year $484 \mathrm{H}$, al-Ghazali, who was at his 30s, headed to Baghdad to teach in a very prestigious madrasah at that time [58]-[61]. His career was brilliant in Baghdad, until he finally occupied the highest position in the "campus".

The high position actually tok al-Ghazali into inner polemic, and eventually he resigned from the prestigious educational institution to uzlah and pursue the Sufi path. At Dzulqa'dah $488 \mathrm{H}$, he went on a pilgrimage. After the pilgrimage, he did not return immediately, but headed for Damascus instead. After that, he headed to Bait al-Maqdis for some time and returned to Damascus and performed i'tikaf in the western tower of the Damascus Mosque. Al-Ghazali sat a lot in the corner of the place of Shaykh Nashr bin Ibrahim A1 Maqdisi in the Jami 'Umawi Mosque (now called al-Ghazaliyah). He lived there and wrote the book lhya Ulumuddin. AlGhazali lived in Syria for about 10 years [62], [63].

Al-Ghazali was a very productive writer. His works are numerous. Among his famous works are Arba'in fi Ush al-Din, Qawa'id al-'Aqa'id, Al-lqtishad fi al-I'tiqad, Tahafut alFalasifah, Faishal al-Tafriqah Bain al-lslam wa Zanadiqah, al-Mustashfa min llm al-Ushul, Mi'yar al-llm, Ma'ariful 'Aqliyah, Misykat al-Anwar, al-Maqshad al-Asna fi Syarhi Asma Allah al-Husna, Mizan al-'Amal, al-Qisthas al-Mustaqim, Raudhat al-Thalibin wa Umdat al-Salikin, al-Risalah al-Laduniyah, lhya' Ulum al-Din, al-Munqidz min al-Dhalal, Bidayah al-Hidayah, and some other books which have significant influence to the global society [64]-[67].

\subsection{Al-Ghazali's Enactive-Metaphor About Qalb (Heart)}

Al-Ghazali discussed Qalb in a long, wide and clear manner in Ihya Ulum al-Din Juz III. To make it easier for learners, al-Ghazali used metaphorical media in accordance with the circumstances of the 11th century AD when the book was written. Al-Ghazali's distinctive feature in explaining concepts is the use of metaphors and analogies that make it easy for 
learners to grasp his ideas. Among the complex concepts explained clearly by al-Ghazali is the concept of qalb (heart).

In explaining the properties of qalb, al-Ghazali used 4 metaphors, namely qalb is like a mirror, a fortress, a kingdom, and a lake. These metaphors will be discussed and analyzed using modern instructional media theory from Bruner's theory and theoretical developments

\section{Metaphor \# 1: Qalb is Like a Mirror}

For al-Ghazali, qalb (heart) is the locus of knowledge (mahal al-ilm). Qalb is a subtle aspect that governs all parts of the body. It is the qalb that is obeyed and served by all parts of the body. His relationship with knowledge, qalb is metaphorized by al-Ghazali like a mirror. The mirror can catch colorful objects. In essence, these objects are knowledge, while the mirror is the heart. There are 5 (five) constraints for the mirror in capturing objects which are also the weakness of the mirror. It is as the constraints and weaknesses of the qalb in capturing the object of knowledge, wisdom, and guidance. These five constraints should be understood by mirror and heart users in order to maximize their role [68]. The five constrains are:

- The first constraint is imperfection, i.e., currently mirrors have not been completely manufactured. At that time the mirror was still in the manufacturing process at the factory and was still in the polishing process. In such condition, the mirror cannot reflect the image completely, it is not clear yet because the construction is not yet perfect. This situation is similar to the heart in the childhood phase. Children's hearts cannot fully grasp the object of ma'lumat (sciences) because these hearts are not yet perfect. Children's hearts are still on the way to perfection.

- The second constrain is the presence of dirt, stains, and mold that accumulate on the mirror surface. Even though the mirror is perfectly crafted, dirt, stains, mold can prevent objects from catching on the mirror. A dirty mirror cannot perfectly reflect the image of the object it captures. In this context, qalb will be constrained and even experience malfunction to capture knowledge, wisdom, and guidance because of dirt, stains, cloudiness, and mold. Dirt, cloudy, and fungus and other qalb diseases are caused by disobedience and evil aspects that accumulate on the surface of the qalb. Ugliness and immorality occur because of the wrong setting of lust. Stains and dirt that arise from ugliness and immorality can hinder the clarity and clarity of qalb in capturing knowledge, wisdom, and guidance.

- The third obstacle is that the mirror is moved or shifted so that the object that is actually being reflected does not enter the mirror frame, even though the mirror is very clear. Moreover, if the object in question is behind the mirror, the object will escape the mirror reflection. In other words, even though the mirror is very clear, it cannot reflect the object behind it. This is the same as qalb which does not face the object to be reflected, namely knowledge, wisdom, and guidance. Everything will not be caught by the qalb because of its existence behind the "frame" of the heart. Even if the qalb is clear, it will be empty of the essential object sought.

- The fourth constraint is a barrier (hijab) between the mirror and the object to be seen. One of the weaknesses of the mirror is that it cannot reflect on objects if there is a barrier or covering between the two. This is like qalb, he cannot grasp the object of knowledge, whether related to Allah (al-Haqq), knowledge, wisdom, and guidance, if there is a barrier between qalb and that knowledge. Among these barriers, in addition to lust, are old beliefs that cause stubbornness and pride.

- The inability of a person to direct the mirror to the desired object, so that the person has a difficulty using the mirror for his actual needs. It is the same as the qalb, in the 
way that the person is not able to direct his heart to obtain ma'lumat (knowledge, wisdom, and guidance). To get information is nothing more than direct direction with precise precision, i.e., tadzakkur atau tafakkur. Metaphorical media Qalb is like a mirror show in Table 1.

Table 1. Metaphorical Media: Qalb is Like a Mirror

\begin{tabular}{|c|c|c|}
\hline No & Mirror & Qalb (Heart) \\
\hline 1. & $\begin{array}{l}\text { Can reflect physical objects (objects of shape } \\
\text { and color) in front of it with some conditions. }\end{array}$ & $\begin{array}{l}\text { Can reflect spiritual objects called ma'lumat } \\
\text { (knowledge): divine (ilahiyah), knowledge, } \\
\text { wisdom (hikmah), and guidance (hidayah) with } \\
\text { some conditions. }\end{array}$ \\
\hline 2. & $\begin{array}{l}\text { Condition \# 1: The mirror that is still in the } \\
\text { process of making, it cannot capture and cannot } \\
\text { perfectly reflect the object because the mirror is } \\
\text { not clear yet. }\end{array}$ & $\begin{array}{l}\text { Condition \# 1: Children's qalb (shabiy) has not } \\
\text { been able to grasp the spiritual object } \\
\text { (ma'lumat) perfectly, because it's still at the } \\
\text { stage of development. }\end{array}$ \\
\hline 3. & $\begin{array}{l}\text { Condition \# 2: A mirror that is dirty with } \\
\text { smudges cannot perfectly capture the object in } \\
\text { front of it, even though it is perfectly crafted. } \\
\text { The more stains, the more malfunctioning the } \\
\text { mirror will be to reflect. }\end{array}$ & $\begin{array}{l}\text { Condition \# 2: Dirty qalb caused by sin and } \\
\text { immorality will not be able to capture ma'lumat } \\
\text { of spiritual objects (tajalli/manifestasi ilahi, } \\
\text { ilmu, hikmah, and hidayah), the more sins and } \\
\text { immorality, the more malfunctioning in } \\
\text { reflecting ma'lumat (knowledge). }\end{array}$ \\
\hline 4. & $\begin{array}{l}\text { Condition \# 3: A mirror is unable to capture } \\
\text { objects behind it. }\end{array}$ & $\begin{array}{l}\text { Condition \# 3: Qalb can not catch the ma'lumat } \\
\text { if it does not appear (iqbal). }\end{array}$ \\
\hline 5. & $\begin{array}{l}\text { Condition \# 4: A mirror cannot capture / reflect } \\
\text { the desired object if it is covered with satyr } \\
(\text { hijab). }\end{array}$ & $\begin{array}{l}\text { Condition \# 4: Qalb is unable to reflect on and } \\
\text { capture spiritual objects (ma'lumat) if it is } \\
\text { obstructed (veiled). }\end{array}$ \\
\hline 6. & $\begin{array}{l}\text { Condition \# 5: A mirror will be difficult to } \\
\text { reflect objects permanently if, it is not focused } \\
\text { on the object to be reflected. }\end{array}$ & $\begin{array}{l}\text { Condition \# 6: Qalb will find it difficult to } \\
\text { capture spiritual objects if the owner is not able } \\
\text { to focus his heart to see (musyahadah) spiritual } \\
\text { objects (ma'lumat) }\end{array}$ \\
\hline
\end{tabular}

2. Metaphor \# 2: Qalb is like a Fortress

In explaining the conflict between Satan and humans, Al-Ghazali explained that qalb is metaphorized by hisn (fortress) and Satan is his enemy. Satan wants to enter the fort and then take it over. Therefore, there was no other way for humans to guard the fort. For al-Ghazali, it is urgent for the fort owner to be safe from Satan's annexation.

In warfare, the fort is the last place of defense of a power. If other places as the territory of a power have been controlled by the enemy, then the fort is the last defense. If the fortress as the last place of defense has been controlled by the enemy, that power will end. Power ends and new powers change, that is, the territory is controlled by the enemy. The owner of power is captured and controlled by the enemy. In this context, the fort functions as a protector from enemies from outside (external enemies). As a shelter, the fort has a door to enter, it also has windows to watch the enemy's movements. After the owner enters and take cover in the fortress, the occupants of the fort must close the doors, the windows, and the other holes of the fort tightly, so that the enemy could not enter. The owner of the fort should never open doors, windows and other openings for the enemy in the shelter. If that is done, it will certainly be very 
dangerous for the owner of the fort. The enemy will take control of the fort and take the owner of the fort. Likewise, qalb is analogized by al-Ghazali as a fortress. It is a treasure trove of treasures and humanity's last stand. If the other organs (eyes, ears, other senses and the nafs) have been controlled by the enemy, then the last line of defense is qalb. Qalb has doors and windows which must be closed tightly. This is intended to make the eternal enemy of humanity (Satan) unable to enter and unable to control humans through mastery of his qalb. The owner of qalb must never open the door of his qalb for the devil's entry. Among the the main entries (abwal ad-'adzimah) for iblis (madakhil al-syaithan) are al-ghadhab-syahwah (anger and desire), hasad wa al-hirs (jealousy and greed), al-siba'i min al-tha'ami (stomach full of too much food), hubb al-tazayyun (fond of making up/decoration), thama' (hope other than Allah), al-ajalah (hurries), al-dahahim wa al-dananir (money), al-tawashshul wa al-ta'asshshub li almadzahib (fanatical on madzhab fiqh and kalam). Metaphorical media Qalb is like a fortress show in Table 2.

Table 2. Metaphorical Media: Qalb is Like a Fortress

\begin{tabular}{|c|c|c|}
\hline No & Fortress & Qalb \\
\hline 1. & $\begin{array}{l}\text { A place of shelter from enemies and a place to } \\
\text { strategize against them }\end{array}$ & A shelter from enemies \\
\hline 2. & External enemy: invaders & External enemy: Satan \\
\hline 2. & Having doors and spots for stalking the enemy & Having doors and windows \\
\hline 3. & $\begin{array}{l}\text { In order for safe protection, and avoiding } \\
\text { enemies from controlling the fort, all entrances } \\
\text { and holes in the fort must be closed tightly }\end{array}$ & $\begin{array}{l}\text { For safe protection, and avoiding the devil } \\
\text { from entering, all doors and windows must be } \\
\text { closed tightly. }\end{array}$ \\
\hline 4. & $\begin{array}{l}\text { Enemies can enter through the main door or other } \\
\text { doors. }\end{array}$ & $\begin{array}{l}\text { Among the the main entries (abwal a- } \\
\text { 'adzimah) are al-ghadhab-syahwah (anger } \\
\text { and desire), hasad wa al-hirs (jealousy and } \\
\text { greed), al-siba'i min al-tha'ami (stomach full } \\
\text { of too much food), hubb al-tazayyun (fond of } \\
\text { making up/decoration), thama' (hope other } \\
\text { than Allah), al-ajalah (hurries), al-dahahim } \\
\text { wa al-dananir (money), al-tawashshul wa al- } \\
\text { ta'asshshub li al-madzahib (fanatical on } \\
\text { madzhab figh and kalam). }\end{array}$ \\
\hline
\end{tabular}

3. Metaphor \# 3: Qalb is Like a Kingdom

Qalb was metaphorized by al-Ghazali as King. The realm of the king is his body. In carrying out his duties, the King has assistants, namely prime minister (wazir), and soldiers (aljund). The prime minister, or patih (Javanese language), is the king assistant to handle governance affairs. In his life, a king is accompanied by his wife(s), and there are the policemen of the kingdom to enforce the law.

The prime minister's job is to assist the King in government matters. He is usually assisted by ministers. In government affairs, they often have desires or targets. They have data about his reign to report to the king. The king will give the final decision of a problem in his kingdom. In the kingdom there are also evil servants who like to steal, rob, cheat and other evil deeds, so we need syurthah (police) or jundun (soldiers) to secure the kingdom and bromocorah (criminals). The expectations of a king is to achieve the welfare of his entire kingdom. 
In a spiritual context, qalb is the King. The king is in control of his physique. The prime minister is $a q l$. The king and prime minister are assisted by the jundun (army). According to alGhazali, there are soldiers who can be seen with the naked eyes, and some that can be seen only with the heart's eye (al-bashirah). All these soldiers were created by Allah to obey the King (qalb). The soldiers that can be seen between the eyes are the hands, feet, eyes, ears, mouths, and all the physical parts of the body. Likewise, the inner qualities of each part of the body, such as the ability to strike for the hands, step for the feet, literacy for the eyes, hearing for the ears, and other ability of the five senses. Everything is formatted (majbul) to obey the qalb. If the qalb says "literate", then the eyes immediately wake up [68]. In such context, al-Ghazali explained as follows:

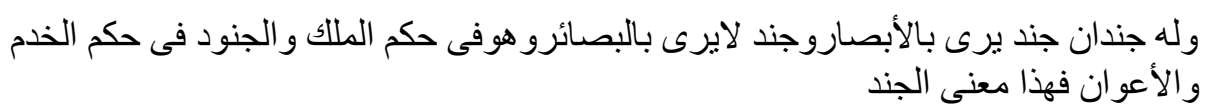

In addition to the five sensory aspects, there are spiritual soldiers, namely syahwah and ghadhab. Al-Ghazali described them as the companions of the King's (qalb) journey to Allah. They were provided to serve the king. However, during the journey, the inner soldiers (syahwah and ghadhab) sometimes disobeyed the king. The dispersion of this army (syahwah and ghadhab) actually ruined the King's journey. The disobedience of lust and ghadhab caused the king's journey to stop.

A conspiracy between criminals (evil royal citizens) and the authorities is very possible. Often in the kingdom there was an evil conspiracy between the King's wives, the prime minister, and the soldiers to undermine, overthrow, or control the king's power. This is in a spiritual context as well as a conspiracy between criminals (thieves, corruptors, jundun-lust), and ministers (wazir, aql) and soldiers (jundun ghadhab). The plot against the king was complete. However, the king still had other inner soldiers who were still clear, namely knowledge and wisdom that could spiritually provide support for the king's journey [68].

The duty of jundun ghadhabiyah is to maintain state security from crimes of lust (internal enemies) such as self-desire to steal, get drunk, rob, take drugs, and so on. In addition, soldiers (jundun) are responsible with protecting the territory from enemy attacks from outside (foreign) such as the annexation of the territory and so on. However, if the quwaah ghadhabiyah of this jundun slips, a spiritual mafia phenomenon will occur, namely the conspiracy of the spiritual aspect to bend and arrest qalb as its king in the spiritual realm. Aql started getting drunk, cheating, stealing/corruption and other evil behavior, supported by syahwah (desire for enjoyment), and supported by quwwah ghadhab (I/ army). The king will be disturbed and even find it difficult to regulate the balance of his spiritual territory, or even the practical steps taken by the king is to follow the wishes of the mafia. The King will be crushed. The king lost his power because in fact he was governed by this spiritual mafia. Spiritual apparatus shows in Table 3. 
Table 3. The Spiritual Apparatus

\begin{tabular}{cll}
\hline No. & Spiritual Aspects & Metaphor \\
\hline 1. & al-Qalbu & King \\
2. & Mamlakah (kingdom) & Kingdom (al-badan) \\
3. 'Aql (al- 'aql) & Wazir,patih, prime minister \\
4. al-Jund al-dhahir and batin & The five senses and their functions \\
5. & al-Jund al-Bathini (syahwah, ghadhab, ilmu, & Spiritual Soldiers (syahwah, ghadhab, \\
& hikmah) & Knowledge, hikmah) \\
6. & Ashab al-mirah al-tha'am, al-makr & Food thieves, rioters, criminals \\
7. & Al-Qasd, safar ila Allah & The purpose of journey is welfare \\
\hline
\end{tabular}

4. Metaphor \# 4: Qalb is like a Lake

The heart is metaphorized by al-Ghazali like al-khawd (lake). This qalb metaphor is associated with qalb's ability to gain knowledge. Lake water usually comes from rivers whose water collects in the lake. The rivers flow from upstream to the lake. In the middle of a river trip, river water often carries garbage, dirt, scouring of the soil beside the river that is passed, and other types of garbage. At least there are two characteristics of a lake in relation to the flow of river water: a) its water is dirty because rivers bring all kinds of garbage with it, b) the volume of river water is sometime high and low. In rainy season, the volume of water is high, while in dry season, the volume is low. According to Imam al-Ghazali, to avoid the lake being contaminated by rubbish carried by river water, the effort that needs to be done is to close the river flow that carries the dirt to the lake. In order for the water to remain plentiful, the lake must be dug until the lake emits and spurts water from within. If this is done, the lake will be clean and water will be abundant at any time.

Qalb, for al-Ghazali, is like a lake. A lake is a source of water. this is the same as qalb. Qalb is the source and locus of knowledge. The peak of knowledge, namely ma'rifatullah, is in qalb. Knowledge that is in the heart can be obtained through the five senses (khawas al-khams), i.e. through sight, hearing, smell, touch, and taste, which are then processed by aql (both imaginative and estimated/wahmi) and then forwarded to qalb as its final estuary. This is often called special science (knowledge obtained through the senses through the learning process). Knowledge obtained through the five senses is often tainted with sensory wastes (both visual, auditory, tactical, and other sensory wastes).

Spiritual wastes that enter through these senses can then pollute the qalb. Qalb is veiled with spiritual waste which enters through sight, hearing, smell, touch and taste. Because the wastes enter through the five senses, the five senses must be closed with khalwat (seclusion). Through seclusion, one can: 1) close the rivers of senses that flow data mixed with waste to qalb through $a q l, 2$ ) have the opportunity to dig a lake (qalb) with dzikrullah, then it will emit water from the existence of springs (a source of knowledge and wisdom) which can be obtained through ladunni knowledge (knowledge of khudhuri) resulted from closeness of a seeker to Allah. According to Imam al-Ghazali, there are two ways to gain knowledge, namely by learning (ta'allum) and by sharpening the qalb. A sharp qalb is like digging the ground to a certain depth which eventually emits water from within. Meanwhile, the acquisition of knowledge by learning (ta'allum) is done by utilizing and empowering the five senses (al-khawas al-khams). Knowledge obtained through the five senses contains waste of the five senses (visual, auditory, and tactile) and has a relatively shallow level of understanding and is less well-rooted. In the context of special knowledge with ta'allum level or scientific degree, it is usually only up to the 
ain al-yaqin level (the level of belief based on sensory witnessing), even at the lower level, namely ilm al-yaqin (the level of belief based on perception). While the knowledge of khudhuri or inspiration or ladunni reaches the level of haqq al-yaqin (the level of belief based on actual facts). Metaphorical media Qalb is like the like show in Table 4.

Table 4. Metaphorical Media: Qalb is Like the Lake

\begin{tabular}{|c|c|c|}
\hline No & Al-Khawdh/Lake & Qalb \\
\hline 1. & Locus of water & $\begin{array}{l}\text { Lokus ma'lumat (objek spiritual) meliputi: } \\
\text { tajalli (manifestasi) ilahi, ilmu, ma'rifah, } \\
\text { hikmah, dan hidayah }\end{array}$ \\
\hline 2. & $\begin{array}{l}\text { The supply of lake water is from the rivers } \\
\text { which flow to the lake. }\end{array}$ & $\begin{array}{l}\text { Ma'lumat is supplied by five senses (al-khaws } \\
\text { al-khams) }\end{array}$ \\
\hline 3. & Rivers & Five senses \\
\hline 4. & $\begin{array}{l}\text { Rivers carry sewage, such as waste, soil, etc., } \\
\text { which causes the lake dirty. }\end{array}$ & $\begin{array}{l}\text { Ma'lumat in the qalb becomes dirty because } \\
\text { of the contamination of the dirt of the five } \\
\text { senses. }\end{array}$ \\
\hline 5. & $\begin{array}{l}\text { The lake waste comes from river water which } \\
\text { sweeps away various things waste, soil } \\
\text { sediment, garbage, etc. }\end{array}$ & $\begin{array}{l}\text { The spiritual impurities come from visual } \\
\text { waste, auditory waste, and other waste that } \\
\text { comes from the five senses. }\end{array}$ \\
\hline 6. & $\begin{array}{l}\text { The way to stop river waste from entering the } \\
\text { lake is by stopping the supply of river water that } \\
\text { carries waste }\end{array}$ & $\begin{array}{l}\text { The way to stop the waste that comes from } \\
\text { visual, auditory, and other waste that comes } \\
\text { from the five senses is by closing the five } \\
\text { senses. }\end{array}$ \\
\hline 7. & $\begin{array}{l}\text { Digging the lake to bring out a clear spring from } \\
\text { within as the water supply, not from the river } \\
\text { streams }\end{array}$ & $\begin{array}{l}\text { Doing khawat with dzikir activities and good } \\
\text { deeds to purify the knowledge and resulting in } \\
\text { the absence of spiritual waste }\end{array}$ \\
\hline
\end{tabular}

\subsection{Discussion}

Imam al-Ghazali often uses metaphors to explain the concepts of Sufism [68]. There are so many themes in Sufism that are subtle and unseen. Usually a Sufi, like al-Ghazali, can understand this concept through riyadhah (spiritual training) and spiritual practice [69]. The quality of understanding (level of haqq al-yaqin) about spiritual anatomy and its relations, as well as knowledge of Allah, can only be attained through direct experience (khudhuri), which in the terms of Bruner's Learning Media Theory is called enactive (direct learning).

Furthermore, al-Ghazali shared the knowledge of the results of direct experience (khudhuri, enactive or direct learning) with students or colleagues with a conative approach. The technique used by al-Ghazali in conveying the concept of Sufism, especially the topic of qalb, is conveyed metaphorically enactive, i.e., the metaphor of direct experience.

According to Bruner, the learning media for enactive level involves all human modalities as learners, namely visual, auditory, and kinesthetic capital. With the combination of all these modalities, the concept can be better accepted compared to the iconic and symbolic levels [70][76]. In the implementation of his metaphorical-enactive message delivery, al-Ghazali empowered aspects as mentioned by Ibn Sina (d.1032 AD) with quwwah khayyaliyah (imaginative power) and quwwah wahmiyah (estimative power), and quwwah aqliyah (aqliyah 
power). At the imaginative level, learners are invited to make metaphoric associations between the concepts in Sufi and their metaphors. Furthermore, students are invited to make estimates (analysis, consistency, and evaluation) of the metaphors understood at the hayyali level. The last stage is the stage of "decision making" from the knowledge obtained through the process of metaphoric association, analysis-synthesis-evaluation. This is the role of qiwwah aqliyah as the term introduced by Ibn Sina.

At the khayyaliyah (imaginative) level, al-Ghazali used mirror, kingdom, fortress, and lake as a metaphor for $a l$-qalb. In the first level, students' imaginations will be invited to fly towards the metaphor of these objects. Furthermore, at the second level, wahmiyah (estimative), students are invited to analyze, detail, and synthesize the potentials inherent in these metaphorical objects. Finally, in the final stage (aqliyyah) students are invited to discover the real knowledge, nature, and reality to be understood and acted on. This is what Ibn Araby referred to as nadhari (theoretically understood reality) and amaly (action).

The power of metaphors in conveying messages (communication) can serve to affirm and imprint on the mind, belief, and behavior. Metaphors are capable of displaying, affirming, or growing character/quality through accentuating the qualities/characters of the entity [77], [78]. Metaphors are a form of human sophistication, because with metaphors humans use natural power, imagination (hayyaliyah), estimation (quwwah wahmiyah), and the finding of behavioral wisdom (quwwah aqliyyah).

\section{Conclusion}

Al-Ghazali used the media on Sufism themes which theoretically and practically could develop the abilities of human understanding. There are three powers that can be active with the media used by al-Ghazali, namely imaginative power (khayyaliyah), estimative (wahmiyah), and aqliyah, and this is what al-Ghazali called, which is the essence of man. The characteristics of the media used by al-Ghazali are: 1) universal (can be found everywhere), 2) lifelong (existing all the time), 3) always contextual, both traditional and modern. The metaphorenactive used makes al-Ghazali media have a "comprehensive mental image" character.

\section{References}

[1] N. Zubaydillo, "Hudjwiri and the role of HIS 'Kashf UL-Makhjoob' in the Sufi History," Acad. An Int. Multidiscip. Res. J., vol. 8, no. 6, pp. 81-85, 2018.

[2] A. Rahmonzoda, "The Place of Mir Sayyid Ali Hamedani in the Development of Sufism and Tajiki Literature," J. Cult. Lit. Linguist. Res. Cent. Asia, vol. 16, no. 44, pp. 27-41, 2016.

[3] J. A. Rohmana, "Sundanese Sufi and Religious Diversity in the Archipelago: The Pluralistic Vision of Haji Hasan Mustapa (1852-1930),” Kawalu J. Local Cult., vol. 5, no. 1, pp. 34-60, 2018.

[4] M. Ellison and H. McClure, "The way of tasawwuf," Routledge Companion to Perform. Philos., p. 42, 2020.

[5] S. Bokir and E. Olmedo, "The Significance of the Trope of the Belly in Silko's Ceremony," Int. J. Lang. Lit. Linguist., vol. 1, no. 4, pp. 275-279, 2015.

[6] D. S. Nouriani, "Islamic Cultures and Jungian Analysis," Jung J., vol. 11, no. 3, pp. 9-25, 2017.

[7] B. Al Hibra, L. Hakim, and T. Sudarwanto, "Development of Vlog Learning Media (Video Tutorial) on Student Materials. Tax at SMK PGRI 1 Jombang,” Int. J. Educ. Res. Rev., vol. 4, no. 3, pp. 435$438,2019$. 
[8] S. Sahronih, A. Purwanto, and M. Sumantri, "The effect of use interactive learning media environment-based and learning motivation on science learning outcomes," Int. J. Educ. Vocat. Stud., vol. 2, no. 3, 2020.

[9] M. Aksa, "Classification and Characteristics of Historical Learning Media," in International Conference on Teacher Training and Education 2017 (ICTTE 2017), 2017.

[10] [M. A. Ramdhani and H. Muhammadiyah, "The criteria of learning media selection for character education in higher education," 2015.

[11] Y. J. Winarto, "Efforts to Increase the Pedagogics of Teachers in Making IT-Based Learning Media in the 4.0 Era," in 3rd International Conference on Education Innovation (ICEI 2019), 2019.

[12] Suwito NS, Transformasi Sosial: Kajian Epistemologis Pemikiran Islam Modern Ali Syari'ati. Yogyakarta \& Purwokerto: Unngun Media dan STAIN Press, 2004.

[13] T. Lickona, "The teacher's role in character education," J. Educ., vol. 179, no. 2, pp. 63-80, 1997.

[14] T. Lickona, "Eleven principles of effective character education," J. Moral Educ., vol. 25, no. 1, pp. 93-100, 1996.

[15] U. A. IZZATI, B. S. BACHRI, M. Sahid, and D. E. Indriani, "Character Education: Gender differences in Moral Knowing, Moral Feeling, and Moral Action in Elementary Schools in Indonesia,” J. Educ. Gift. Young Sci., vol. 7, no. 3, pp. 547-556, 2019.

[16] A. S. Suwito, S. Aziz, A. C. Harimi, and M. Mualim, "The Curriculum of Tahfidz Al-Qur'an at The Mustawa Awwal of Pesantren Darul Quran Al-Karim, Baturraden, Central Java,” 2019.

[17] H. Dent, K. Nielsen, and T. Ward, "Correctional rehabilitation and human functioning: An embodied, embedded, and enactive approach,” Aggress. Violent Behav., vol. 51, p. 101383, 2020.

[18] R.-M. Rodríguez-Jiménez and S. García-Merino, "Enactive and Embodied Learning In Higher Education,” J. Funct. Neurol. Rehabil. Ergon., vol. 7, no. 4, pp. 5-9, 2017.

[19] Y. L. M. Mendoza and M. C. C. Baranauskas, "TangiTime: designing a (socio) enactive experience for deep time in an educational exhibit," in Proceedings of the 18th Brazilian Symposium on Human Factors in Computing Systems, 2019, pp. 1-11.

[20] [20] P. K. Nelson, "Piano Curriculum: What Order Do Teachers Introduce Concepts, What Method Books Teachers Are Using And How Do The Method Books Align With Jerome Bruner's Enactive, Iconic And Symbolic Learning Theory," MTNA e-Journal, vol. 6, no. 4, p. 13, 2015.

[21] S. Mas' ula and A. Fauzan, "The Validity of Enactive Iconic Symbolic Problem Based Learning Model (PBM-ENIKSI) for Elementary School," in 1st International Conference on Education Social Sciences and Humanities (ICESSHum 2019), 2019.

[22] K. L. Madsen, K. Aggerholm, and J.-O. Jensen, "Enactive movement integration: Results from an action research project," Teach. Teach. Educ., vol. 95, p. 103139, 2020.

[23] M. Walls, "The bow and arrow and early human sociality: An enactive perspective on communities and technical practice in the Middle Stone Age," Philos. Technol., vol. 32, no. 2, pp. 265-281, 2019.

[24] S. Gallagher and R. Lindgren, "Enactive metaphors: Learning through full-body engagement," Educ. Psychol. Rev., vol. 27, no. 3, pp. 391-404, 2015.

[25] Z. Xie and Y. Jin, "An extended reinforcement learning framework to model cognitive development with enactive pattern representation," IEEE Trans. Cogn. Dev. Syst., vol. 10, no. 3, pp. 738-750, 2018.

[26] J. C. Van den Herik, "Rules as resources: An ecological-enactive perspective on linguistic normativity," Phenomenol. Cogn. Sci., pp. 1-24, 2020.

[27] J. C. Van Den Herik, "Attentional actions-an ecological-enactive account of utterances of concrete words," Psychol. Lang. Commun., vol. 22, no. 1, pp. 90-123, 2018.

[28] E. M. De Carvalho and G. Rolla, "An enactive-ecological approach to information and uncertainty," Front. Psychol., vol. 11, 2020.

[29] O. G. De la Cerda, P. Humphreys, and M. S. S. Ulloa, "Enactive management: A nurturing technology enabling fresh decision making to cope with conflict situations," Futures, vol. 103, pp. 84-93, 2018.

[30] A. Peeters and M. Segundo-Ortin, "Misplacing memories? An enactive approach to the virtual memory palace," Conscious. Cogn., vol. 76, p. 102834, 2019. 
[31] E. Baggs, V. Raja, and M. L. Anderson, “Extended skill learning,” Front. Psychol., vol. 11, p. 1956, 2020.

[32] J. Bruineberg, J. Kiverstein, and E. Rietveld, "The anticipating brain is not a scientist: the free-energy principle from an ecological-enactive perspective," Synthese, vol. 195, no. 6, pp. 2417-2444, 2018.

[33] J. Soto-Andrade, D. Díaz-Rojas, and P. Reyes-Santander, "Random walks in the didactics of probability: Enactive metaphoric learning sprouts," in Teaching and Learning Stochastics, Springer, 2018, pp. 125-143.

[34] D. Díaz-Rojas and J. Soto-Andrade, "Enactive metaphoric approaches to randomness," 2015.

[35] S. Sorgenfrei, "Hidden or forbidden, elected or rejected: Sufism as 'Islamic esotericism'?," Islam Christ. Relations, vol. 29, no. 2, pp. 145-165, 2018.

[36] D. Abdurahman, "Islam, Sufism, and Character Education in Indonesia History," TAWARIKH, vol. 9, no. 2, pp. 159-176, 2018.

[37] L. Makhasin, "Urban Sufism, media and religious change in Indonesia," Ijtimā'iyya J. Muslim Soc. Res., vol. 1, no. 1, pp. 23-36, 2016.

[38] N. Hofer, Popularisation of Sufism in Ayyubid and Mamluk Egypt, 1173-1325. Edinburgh University Press, 2015.

[39] S. Ns, "Eko-Sufisme: Konsep, Strategi, dan Dampak," Sekolah Pasca Sarjana, 2011.

[40] A. Efendi, "Values of Social Sufism in the Short Story 'Burung Kecil Bersarang di Pohon'(A Little Bird Nesting on the Tree) by Kuntowijoyo," Mediterr. J. Soc. Sci., vol. 6, no. 4, p. 93, 2015.

[41] A. Sururi, A. Kuswanjono, and A. H. Utomo, "Ecological sufism concepts in the thought of Seyyed Hossein Nasr,” Res. Soc. Dev., vol. 9, no. 10, pp. e5769108611-e5769108611, 2020.

[42] D. S. Bano, M. Sohail, and S. S. Hussain, "Curbing extremism through Sufism: a south Asian perspective," South Asian Stud., vol. 30, no. 1, 2020.

[43] M. Sharify-Funk, "Gender and Sufism in Western Scholarship: Contemporary Constructions and Contestations," Stud. Relig. Relig., vol. 49, no. 1, pp. 50-72, 2020.

[44] W. K. Abdul-Hamid and J. H. Hughes, "Integration of religion and spirituality into trauma psychotherapy: An example in Sufism," J. EMDR Pract. Res., vol. 9, no. 3, pp. 150-156, 2015.

[45] C. Melchert, "Origins and early Sufism," Cambridge Companion to Sufism, pp. 12-13, 2015.

[46] R. Rozehnal, Islamic Sufism unbound: Politics and piety in twenty-first century Pakistan. 2016.

[47] A. H. ibn A. Al-Ghazali, Ihya' Ulum al-Din. Ats-Tsurayya, 1982.

[48] F. Munawaroh, "Contribution of moral Sufism learning to Adversity Quotient," ATTARBIYAH J. Islam. Cult. Educ., vol. 3, no. 1, pp. 46-64, 2018.

[49] S. D. A. Andrabi, "Sufism: Origin and Basic Concepts," Int. J. Cult. Hist., vol. 2, no. 1, pp. 30-36, 2015.

[50] A. L. Karamatilloevich, M. T. Abduvaliyevich, and X. R. Kudratullayevich, "The spiritual connection of Sufism and Tolerance in the works of Jami,” Int. J. Multidiscip. Res. Publ., vol. 2, no. 11, pp. 1-4, 2020.

[51] M. C. W. Suwito, Ah. Zakki Fuad, Arif Hidayat, Ida Novianti, Muflihah, "Language Acquisition Through Sufism (A Case Study of Sufism Concept and Implementation of Learning English through Subconscious-Installing Method [LET-IM] in Kuanta Indonesia)," Asian EFL, vol. 23, no. 3.2, pp. 143--158, 2019.

[52] S. Mahpol et al., "The Implementation of Takhalli Value in Arabic Grammar according to AlQushayri in Na? w al-Qulub alKabir,” Int. J. Acad. Res. Bus. Soc. Sci., vol. 7, no. 12, pp. 558-564, 2017.

[53] S. Supriyadi and M. Jannah, "Pendidikan Karakter Dalam Tasawuf Modern Hamka Dan Tasawuf Transformatif Kontemporer,” Halaqa Islam. Educ. J., vol. 3, no. 2, pp. 91-95, 2020.

[54] I. Z. APRI, "TRANCENDENCE AND ACUTUALISATION Studi Fenomenologi Pelajar Pengamal Tarekat Hizib Nahdlatul Wathan," al-Hikmah J. Stud. Islam, vol. 1, no. 1, pp. 47-70, 2020.

[55] I. S. Wekke, A. A. Amiruddin, and M. Wardi, "Epistemology of Laduni Science on Muhammad AlGhazali Thought," Al-Ulum, vol. 18, no. 2, pp. 521-544, 2018.

[56] A. Maulidizen, "Business Ethics: Analysis of al-Ghazali's Economic Thought With Sufism Approach,” RELIGIA, pp. 160-177, 2019. 
[57] A. Elshimi, "Al-Ghazali's integral epistemology: A critical analysis of the jewels of the Quran," 2017.

[58] M. F. Amrullah, "Sejarah Peradaban Islam; Madrasah Nidzam Al-Mulk," HUMANISTIKA J. Keislam., vol. 5, no. 1, pp. 41-56, 2019.

[59] M. Isbir, "Studi tentang Madrasah Nizhamiyah," TASYRI' J. TARBIYAH-SYARI'AH Islam., vol. 24, no. 01, pp. 49-59, 2017.

[60] A. Sugiana, "Islamic Education Perspective Imam Al-Ghazali And Its Relevance With Education In Indonesia," J. Tarb., vol. 26, no. 1, 2019.

[61] S. Syafril, "PEMIKIRAN SUFISTIK Mengenal Biografi Intelektual Imam Al-Ghazali," SYAHADAH J. Ilmu al-Qur'an dan Keislam., vol. 5, no. 2, 2017.

[62] J. Inglis, "The Relationship between Averroes and al-Ghazali: As it Presents itself in Averroes' Early Writings, especially in his Commentary on al-Ghazali's al-Mustasfa," in Medieval Philosophy and the Classical Tradition, Routledge, 2005, pp. 52-63.

[63] F. Griffel, "The Relationship between Averroes and al-Ghazālī," Mediev. Philos. Class. Tradit. Islam. Jud. Christ., pp. 2002-2051, 2002.

[64] M. Muttaqien, M. Hatta, and Z. Arifin, "Ethics Relevance of Interpersonal Communication in Ihya Ulun Al-Din with Islamic Communication," Budapest Int. Res. Critics Inst. Humanit. Soc. Sci., vol. 1 , no. 4, pp. 254-264, 2018.

[65] N. Said, "Ghazali's Work and The Influences In Indonesia.” Thesis MA Tidak Diterbitkan, Mcgill University: Institute of Islamic Studies, 1992.

[66] D. Solahudin, "Reconstructing Da'wah of Salafi in Shaikh Muhammad Al-Ghazali Works," Ilmu Dakwah Acad. J. Homilet. Stud., vol. 13, no. 2, pp. 220-232, 2019.

[67] M. Attaran, "Moral Education, Habituation, and Divine Assistance in View of Ghazali," J. Res. Christ. Educ., vol. 24, no. 1, pp. 43-51, 2015.

[68] A. H. ibn A. Al-Ghazali, Ihya Ulum al-Din Jilid III. Kediri: Pesantren Fathul Ulum.

[69] Al-Ghazali, Ihya' 'Ulum al-Din, Juz IV. Maktabah Dar Ihya' al-Kutub al-'Arabiyah.

[70] D. R. Olson, Jerome Bruner: The cognitive revolution in educational theory. Bloomsbury Publishing, 2014.

[71] X. Jiang and K. Perkins, "A Conceptual Paper on the Application of the Picture Word Inductive Model Using Bruner's Constructivist View of Learning and the Cognitive Load Theory.," Interdiscip. J. Teach. Learn., vol. 3, no. 1, pp. 8-17, 2013.

[72] N. B. Carlisle and Á. Kristjánsson, "How visual working memory contents influence priming of visual attention," Psychol. Res., vol. 82, no. 5, pp. 833-839, 2018.

[73] C. Mattingly, N. C. Lutkehaus, and C. J. Throop, "Bruner's search for meaning: A conversation between psychology and anthropology," Ethos, vol. 36, no. 1, pp. 1-28, 2008.

[74] E. Wenger, N. White, and J. Smith, Learning in communities. 2010.

[75] K. Takaya, "Jerome Bruner's theory of education: From early Bruner to later Bruner," Interchange, vol. 39, no. 1, pp. 1-19, 2008.

[76] J. Bruner, "Jerome Bruner: Reflections of a developmental psychologist," Hum. Dev., vol. 51, no. 1, pp. 101-103, 2008.

[77] H. Handriyotopo, G. R. L. Lastoro, and S. P. Gustami, "APROPRIATION OF METAFORA IN FILM ADVERTISING 'MANDIRI SECURITAS,”' Capture J. Seni Media Rekam, vol. 10, no. 1, pp. 27-39, 2018.

[78] F. A. Husein, "Insight-Teater dan Teknologi Metafor,” MELINTAS, vol. 26, no. 3, pp. 333-338, 2010 